\title{
ASSESSMENT OF THE IMMEDIATE IMPACTS OF THE 2013-2014 DROUGHT ON ECOSYSTEMS OF THE CALIFORNIA CENTRAL COAST
}

\author{
Christopher Potter ${ }^{1}$
}

\begin{abstract}
A methodology was developed to assess the impacts of the historic 2013-2014 drought on ecosystems of California's Central Coast region, using a combination of satellite image analysis and in situ measurements of soil moisture in predominant vegetation types of the region. According to differences in Landsat drought indices for plant water stress and vegetation green cover (NDWI and NDVI, respectively), the geographic areas within the study region that were most severely impacted by the 2013 drought were the inland Carmel Valley in northern Monterey County and the coastal zones around San Simeon Point and Cambria in northern San Luis Obispo County. An expanded area of severe vegetation moisture stress, generally indicated by relative-differenced NDWI values of $>400$, was detected by May 2014 in both of these same geographic areas. For more detailed examination of drought impacts, the entire study region was separated into the 3 predominant vegetation types (grasslands, shrublands, and forests) to examine changes in Landsat NDWI and NDVI in the context of differing plant community responses to severe drought. Results confirmed that higher overall drought stress in 2013 and 2014 was detected in grasslands, compared to shrublands and forests, in both years at all elevations and slopes $>200 \mathrm{~m}$ and $>5 \%$, respectively.
\end{abstract}

Resumen.-Se desarrolló una metodología para evaluar el impacto de la sequía histórica del 2013-2014 en los ecosistemas de la región de la costa central de California, utilizando una combinación de análisis de imágenes satelitales y mediciones in situ de la humedad del suelo en los tipos de vegetación predominantes de la región. De acuerdo a las diferencias en los índices de sequía Landsat para el estrés hídrico de las plantas y la cubierta vegetal (NDWI y NDVI, respectivamente), las áreas geográficas dentro de la región de estudio que fueron más gravemente afectadas por la sequía del 2013 fueron Carmel Valley en el norte del Condado de Monterey, y las zonas costeras alrededor de San Simeon Point y Cambria en el norte de San Luis Obispo County. Un área extensa de estrés de humedad severo en la vegetación, en general indicado por la diferencia relativa de valores NDWI de más de 400, se detectó en mayo del 2014 en estas dos mismas áreas geográficas. Para una revisión más detallada de los impactos de la sequía, toda la región de estudio se dividió en los tres tipos de vegetación predominante (pastizales, matorrales y bosques) para examinar los cambios en Landsat NDWI y NDVI para ver las diferencias en la respuesta de las comunidades de plantas a la sequía severa. Los resultados confirmaron un mayor estrés por la sequía del 2013 y 2014 en los pastizales, en comparación con los matorrales y bosques en ambos años en todas las elevaciones y pendientes de más de 200 metros y $5 \%$, respectivamente.

The year 2013 was the driest on record in California, with a total precipitation of just $30 \%$ of the statewide average (Hanak et al. 2014). The previous statewide record low in 1976 was $56 \%$ of average precipitation. This extreme lack of rainfall during the 2013 and 2014 wet seasons created an unprecedented level of stress on natural ecosystems and agricultural production systems throughout the central regions of the state (Howitt et al. 2014), where there remains a pressing need to develop assessment methods for mitigating local impacts and future risks.

This drought assessment study focused on the Central Coast region, where the wet, cooler climate of the northern California re- gion meets the dry, warmer climate of the southern region (Daly et al. 2008). The highest peaks in the Santa Lucia Mountains on the Central Coast form a wall behind coastal hillsides, which effectively traps cooler marine air (Henson and Usner 1996). This can lead to the formation of steep elevation gradients in air temperature regimes, humidity, and other climatic factors. This region of the state is continuously subjected to extreme climatic events (Hiatt et al. 2012, Potter 2014a), frequent wildfires, and human development impacts, together affecting wildlife populations, native plant communities, soil conservation, riparian zones, and water quality.

1National Aeronautics and Space Administration, Ames Research Center, Moffett Field, CA 94035. E-mail: chris.potter@nasa.gov 


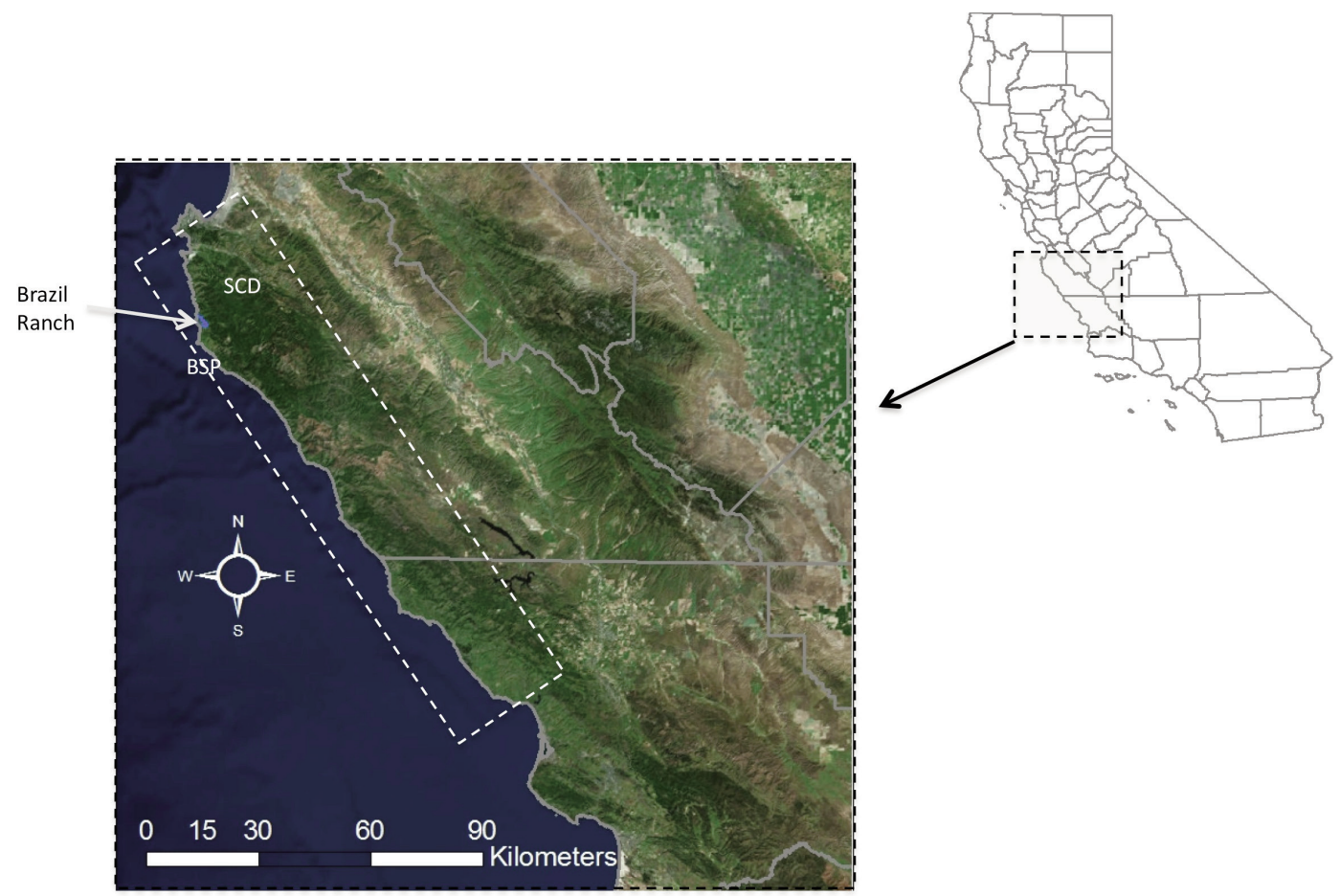

Fig. 1. Central Coast study region within Monterey County and San Luis Obispo County, California. The dashed white outline delineates the general boundaries of the Big Sur subregion of approximately $140 \mathrm{~km}$ on the coast and $30 \mathrm{~km}$ inland.

The ecosystems of California's Central Coast region have a high degree of biological diversity and endemism, and provide critical habitat for a large number of rare, endangered, and threatened animal and plant species (Henson and Usner 1996), including the wild orchid Piperia yadonii, the California Condor (Gymnogyps californianus), California southern sea otter (Enhydra lutris nereis), and the southernmost coast redwoods (Sequoia sempervirens). Mixed herbaceous-shrub vegetation communities dominate the Central Coast region of California near Big Sur (Monterey County).

The objective of this study was to assess the impacts of the historic 2013/14 drought on ecosystems of the Central Coast region using a combination of satellite image analysis and in situ measurements of soil moisture at sites representative of the predominant vegetation types of the region. The novel methodology used differencing of image data for the previous above-average rainfall year in the region to successive years of far-below-average rainfall years. The methodology also controlled for the impacts of recent wildfires on vegetation growth (or regrowth) rates.

\section{Methods}

\section{Study Region}

California's Central Coast region was selected as the study region (Fig. 1). The Big Sur subarea is generally delineated within this region by the $140 \mathrm{~km}$ (90 miles) of coastline from the Carmel River in Monterey County south to the San Carpoforo Creek in San Luis Obispo County, extending about $30 \mathrm{~km}$ inland to the eastern foothills of the Santa Lucia Mountains. The terrain is rugged and undulating, with the steepest elevation gradients on the U.S. Pacific coast (Shreve 1927).

The region has a Mediterranean climate of warm, dry summers and cool, wet winters, with localized summer fog near the coast (Hiatt et al. 2012). Annual rainfall is highly variable and ranges from $40 \mathrm{~cm}$ to $155 \mathrm{~cm}$ throughout the region, with highest event totals normally falling on the higher mountains in the northern extreme of the study area during 
winter storms (Potter 2014a). During the summer, fog and low clouds are frequent along the coast. Mean annual temperature ranges between $10{ }^{\circ} \mathrm{C}$ and $15{ }^{\circ} \mathrm{C}$, from shaded canyon bottoms to exposed ridgetops, respectively.

Hiatt et al. (2012) reported that fog deposition on land around Big Sur commonly peaks in July and August. This increase in fog deposition coincides with the period of lowest rainfall, characteristic of California's Mediterranean climate. Most summer fog deposition measured by Hiatt et al. (2012) at Big Sur occurred during the night and early morning hours. After 9:00, average fog deposition steeply declined, to nearly zero between 14:00 and 18:00. High wind speeds typically accompanied increased rates of fog deposition during periods of low dew-point depression.

Plant growth on the Central Coast can be highly variable from year to year and is generally limited by declines of soil moisture in the summer and by cool temperatures in the winter (Potter 2014a, 2014b). The annual production pattern for coastal grasses is rapid growth in the late fall (November) after the first rains have returned, slow winter growth (December-February), and rapid growth again in spring (March-May) (Shreve 1927, Corbin et al. 2005).

Drier, southeast-facing slopes share a relatively equal distribution of coyote brush (Baccharis pilularis) and California coffeeberry (Rhamnus californica) along with some California sagebrush (Artemisia californica) (Shreve 1927, Henson and Usner 1996). The coastal scrub community is usually a successional plant community that, in the absence of fire, gradually moves into herbaceous (grassland) cover where the soil depth transitions from the shallowest to intermediate depth. The herbaceous plant community includes California annual grassland series and California oatgrass series. Mixed evergreen forest stands around Big Sur are dominated in the valley bottoms by coast redwoods and on steep slopes and ridgetops by tanoaks, live oaks, madrones, manzanitas, pines, and firs (Henson and Usner 1996).

Wildfire is a naturally occurring phenomenon in Mediterranean ecosystems of the California Central Coast. In June and July of 2008, 99,000 ha of the study region was burned by the third-largest forest fire in California's history, the Basin Complex and Indians Fire, on the Monterey Ranger District of the Los Padres National Forest (De Santis et al. 2010). During the recent drought period, the Pfeiffer Ridge Fire burned more than 360 ha of forest over a 5-day period starting on 17 December 2013.

\section{Climate Summary Data}

Monthly climate summaries from 1950 to 2014 for the study area were obtained from the Western Regional Climate Center data portal (Abatzoglou et al. 2009, WRCC 2014). Two long-term data records from National Oceanic and Atmospheric Association Cooperative Stations were available for this study: Big Sur State Park (BSP, National Weather Service [NWS] ID 040790; $36^{\circ} 15^{\prime} \mathrm{N}, 121^{\circ} 47^{\prime} \mathrm{W}$; elevation $320 \mathrm{~m}$ ) and San Clemente Dam (SCD; NWS ID 047731; $36^{\circ} 26^{\prime} \mathrm{N}, 121^{\circ} 42^{\prime} \mathrm{W}$; elevation $180 \mathrm{~m})$. Locations of the stations are shown in Fig. 1.

The BSP record represents the longest complete climate record on the Monterey County coast south of Carmel, dating back to 1950 for rainfall measurements. The station is situated $3.5 \mathrm{~km}$ due east from the ocean at a relatively low elevation. The SCD station is located about $30 \mathrm{~km}$ inland in the Carmel Valley from BSP, on the eastern side of the Santa Lucia Mountains, in a location less influenced by the direct on-shore flow of marine air masses than is BSP.

\section{Soil Moisture Monitoring}

Volumetric water content (VWC) of grassland, shrubland, and forest soils were monitored from 2011 to 2014 at the U.S. Forest Service Brazil Ranch $\left(36^{\circ} 24^{\prime} \mathrm{N}, 121^{\circ} 54^{\prime} \mathrm{W}\right)$ site (Fig. 2, Table 1), located approximately $12 \mathrm{~km}$ northwest of BSP (Potter 2014b). EC-5 frequency domain probes (Decagon Devices, Pullman, WA) were placed at soil depths of $10 \mathrm{~cm}, 30 \mathrm{~cm}$, and $50 \mathrm{~cm}$ for hourly measurements of VWC before and throughout the 2013-2014 drought period. The grassland soils on Serra Ridge were regularly grazed by cattle. The shrubland soils monitored were covered by coastal scrub vegetation on the opposite slope of Serra Ridge. Forested soils under coast redwood stands were monitored along Serra Creek canyon. Predominant soil types on the Brazil Ranch included the Sheridan, the Pfeiffer-Rock Outcrop complex, and the Gamboa-Sur complex. Much of 


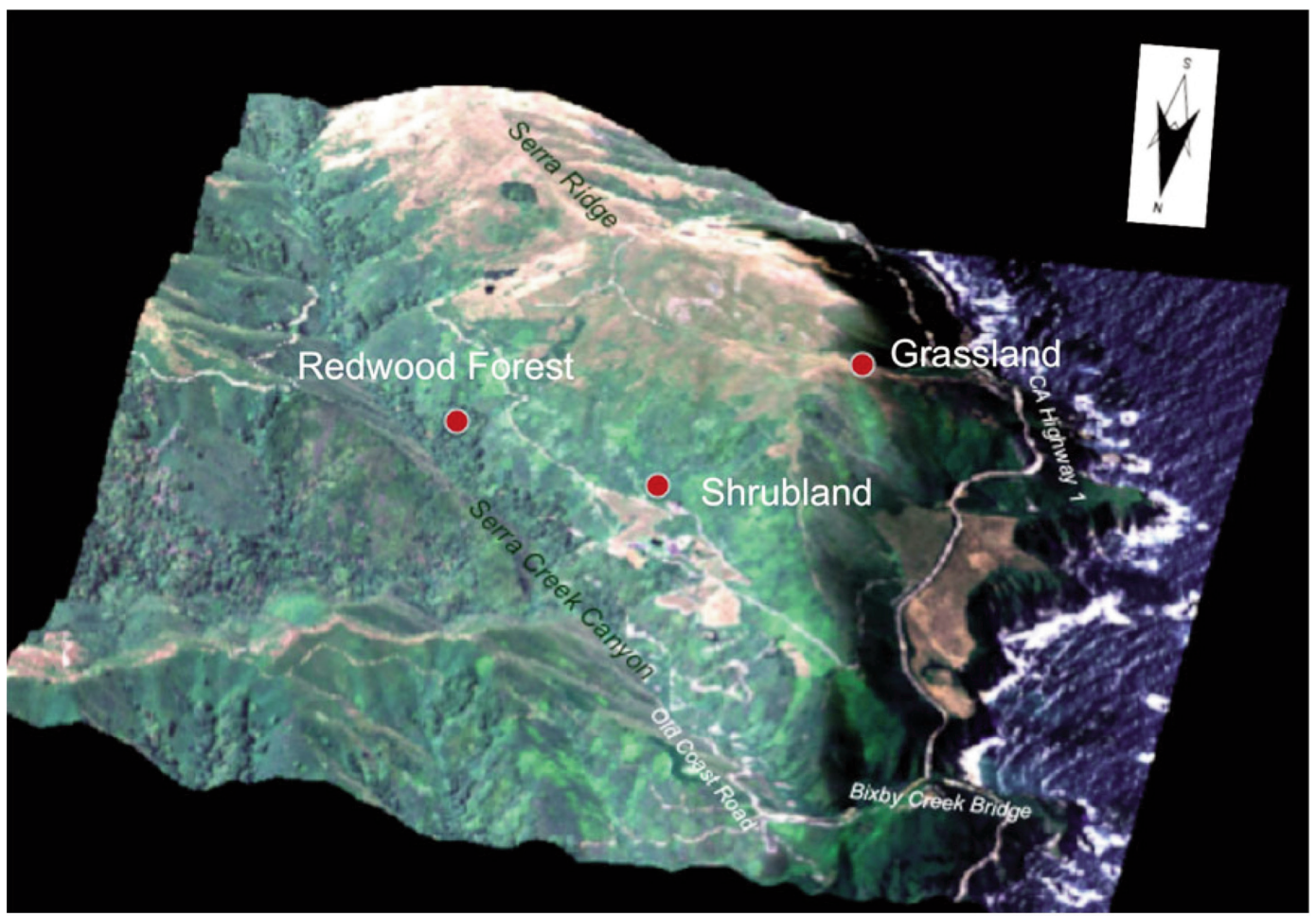

Fig. 2. Brazil Ranch image, with locations of soil moisture measurement stations.

TABLE 1. Site locations for soil moisture monitoring at the Brazil Ranch.

\begin{tabular}{clccc}
\hline Site number & Vegetation cover & Latitude & Longitude & Elevation $(\mathrm{m})$ \\
\hline 1 & Grassland & $36.35556^{\circ} \mathrm{N}$ & $121.89556^{\circ} \mathrm{W}$ & 362 \\
2 & Shrubland & $36.36139^{\circ} \mathrm{N}$ & $121.89056^{\circ} \mathrm{W}$ & 188 \\
3 & Forest & $36.35833^{\circ} \mathrm{N}$ & $121.88222^{\circ} \mathrm{W}$ & 172 \\
\hline
\end{tabular}

the Brazil Ranch property is covered by coarse sandy loam soils on slopes $>30 \%$ (Potter 2014b).

\section{Satellite Image Analysis}

Cloud-free imagery from the Landsat 5 and 8 Enhanced Thematic Mapper sensors was selected from the U.S. Geological Survey (USGS) Earth Explorer data portal (USGS 2014a). Predrought Landsat 5 image data from path/row 43/35 were acquired on 3 May 2010, near the peak of the vegetation growing season on the Central Coast (Potter 2014b). For drought severity mapping, Landsat 8 images on 11 May 2013 and 14 May 2014 were also acquired. By comparing May Landsat data for all years, the methodology effectively controls for seasonal temperature and solar radiation on near-peak seasonal patterns of plant growth or any dieback of canopy green cover.

All Landsat images used in this study were geometrically registered using terrain correction algorithms (Level 1T) applied by the USGS Earth Resources Observation and Science (EROS) Data Center (Sioux Falls, SD), and then converted to at-sensor reflectance following the algorithms from Chander et al. (2009). No further corrections for atmospheric effects were applied, since the reflectance indices used in this study employed nearinfrared (NIR; 0.77-0.90 $\mu \mathrm{m}$ ) and short-wave infrared (SWIR; 1.55-2.29 $\mu \mathrm{m}$ ) wavelengths that are minimally affected by atmospheric scattering (Avery and Berlin 1992, Gao 1996).

The severity of drought stress at $30-\mathrm{m}$ ground resolution across the study region was 
determined using the Landsat normalized difference water index (NDWI; Gao 1996), which has been validated repeatedly in the field as an index of vegetation moisture status (Hunt and Rock 1989, Chuvieco at al. 2002, Dennison et al. 2005), as calculated in the following equation:

$$
\mathrm{NDWI}=\frac{\mathrm{NIR}-\mathrm{SWIR}}{\mathrm{NIR}+\mathrm{SWIR}} .
$$

NDWI (scaled by 1000 to an integer format) is comparable to the Landsat normalized burn ratio used for wildfire severity mapping (Miller and Yool 2002).

The relative-differenced NDWI (RdNDWI) was computed for this study as a comparison of predrought and postdrought surface conditions:

$$
\text { RdNDWI }=\frac{\text { NDWI pre }- \text { NDWI post }}{\sqrt{\text { ABS (NDWI pre) }}},
$$

where ABS indicates the absolute value of the predrought NDWI; this value in the denominator allowed computation of the square root without changing the sign of the RdNDWI. High positive RdNDWI values would represent a decrease in vegetation moisture and high drought stress or wildfire burn severity, whereas near-zero values would represent relatively high vegetation moisture content and no increase in drought stress.

The normalized difference vegetation index (NDVI) from Landsat imagery has been frequently used to monitor live vegetation canopy cover and trajectories of change during and after ecosystem disturbances (Van Wagtendonk and Root 2003, Lentile et al. 2006). NDVI was computed for this study using Landsat bands:

$$
\mathrm{NDVI}=\frac{\mathrm{NIR}-\mathrm{Red}}{\mathrm{NIR}+\mathrm{Red}},
$$

where Red is the reflectance from $0.63 \mathrm{~m}$ to $0.69 \mathrm{~m}$ and NDVI was scaled from 0 to 1000 . Advantages of NDVI for the purpose of vegetation monitoring have been cited to include its mathematical simplicity and ease of comparability across numerous multispectral remote sensing platforms (Lentile et al. 2006). Low NDVI values (near 0 ) indicate barren land cover whereas high NDVI values (near 1000) indicate dense canopy vegetation cover. Negative NDVI values often indicate water bodies.

\section{Spatial Data Layers}

Vegetation types for the study area were determined based on the National Agricultural Statistics Service California Cropland Data Layer (CDL) from 2012 (National Agricultural Statistics Service 2012). The CDL, which is a raster image, is a georeferenced, crop-specific land-cover data layer with a ground resolution of $30 \mathrm{~m}$. The CDL is produced using satellite imagery from the Landsat sensor collected during the current growing season. Additional land-cover maps were used as zonal layers for classifying results, including the USGS National Elevation Dataset (USGS 2014b), the USGS National Land Cover Database 2001 (USGS 2001), and the National Aeronautics and Space Administration Moderate Resolution Imaging Spectroradiometer (NASA 2014) 250-m resolution 16 -day vegetation index composites. Based on the 2012 CDL layer, the 3 predominant vegetation types in the study region (Fig. 3) were grasslands (estimated to cover 517,370 ha), shrublands (estimated to cover 556,350 ha), and forests (estimated to cover 146,110 ha). Cropland areas of the region defined by the CDL were not included in this study because of the prevalence of irrigation to alleviate drought stress and the frequency of crop type rotation from year to year.

Perimeter boundaries for wildfires that occurred within the study region since 2005 were delineated from the database compiled by the California Department of Forestry, Fire and Resource Assessment Program (2014). Burn severity classes at 30-m resolution for the 2008 Basin Complex fire were determined by the Monitoring Trends in Burn Severity (MTBS) project, which has consistently mapped the burn severity (from RdNBR methods) and perimeters of fires $>405$ ha (1000 acres) across the USA from 1984 to the present (Eidenshink et al. 2007). The MTBS project is conducted through a partnership between the USGS EROS and the USDA Forest Service Remote Sensing Applications Center. Although there have been other large wildfires in the study region prior to 2005 , only the most recent fires (since 2005) were examined, due to rapid postfire vegetation regrowth measured and verified by Li and Potter (2012). 

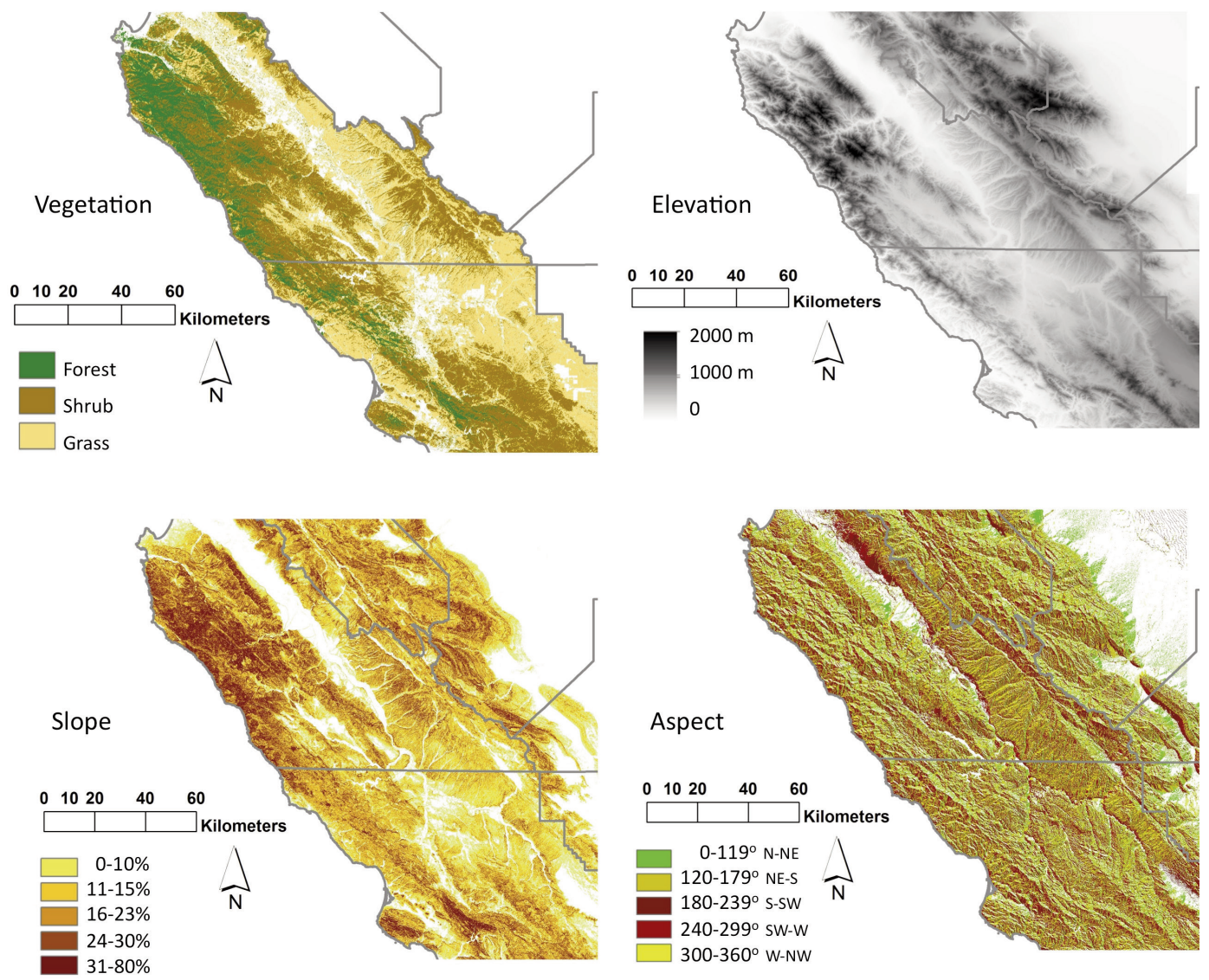

Fig. 3. Regional map layers for vegetation, elevation, slope, and aspect, all at a 30-m spatial resolution.

Elevation, slope, and aspect were determined at a $30-\mathrm{m}$ spatial resolution (Fig. 3) from the USGS National Elevation Dataset (USGS 2014b). For each 30-m cell, slope (as a percentage) was calculated as the maximum rate of change in elevation value from that cell to its neighbors to determine the steepest downhill descent from the cell. Aspect was calculated by fitting a plane to the z-values of a $3 \times 3$ cell neighborhood around each $30-\mathrm{m}$ cell (Burrough and McDonell 1998). The direction that the plane faced was set as the aspect for the cell. Aspect was expressed in degrees, moving clockwise from 0 (due north) to 360 (again due north).

\section{Statistical Analysis}

Tests of statistical significance between sampled groups of points were carried out using the 2-sample Kolmogorov-Smirnov $(\mathrm{K}-\mathrm{S})$ test, a nonparametric method that compares the cumulative distributions of 2 data sets (Lehmann 2006). The K-S test does not assume that data were sampled from Gaussian distributions (or any other defined distributions), nor can its results be affected by changing data ranks or by numerical (e.g., logarithmic) transformations. The $\mathrm{K}-\mathrm{S}$ test reports the maximum difference between the 2 cumulative distributions and calculates a $P$ value from that difference and the sample sizes. It tests the null hypothesis that both groups were sampled from populations with identical distributions according to different medians, variances, or outliers. If the $\mathrm{K}-\mathrm{S} P$ value is small (i.e., <0.05), it can be concluded that the 2 groups were sampled from populations with significantly different distributions.

\section{RESUlTS}

\section{Regional Rainfall Deficits}

For 2013, precipitation totaled $18.5 \mathrm{~cm}$ at the BSP weather station, which was only 


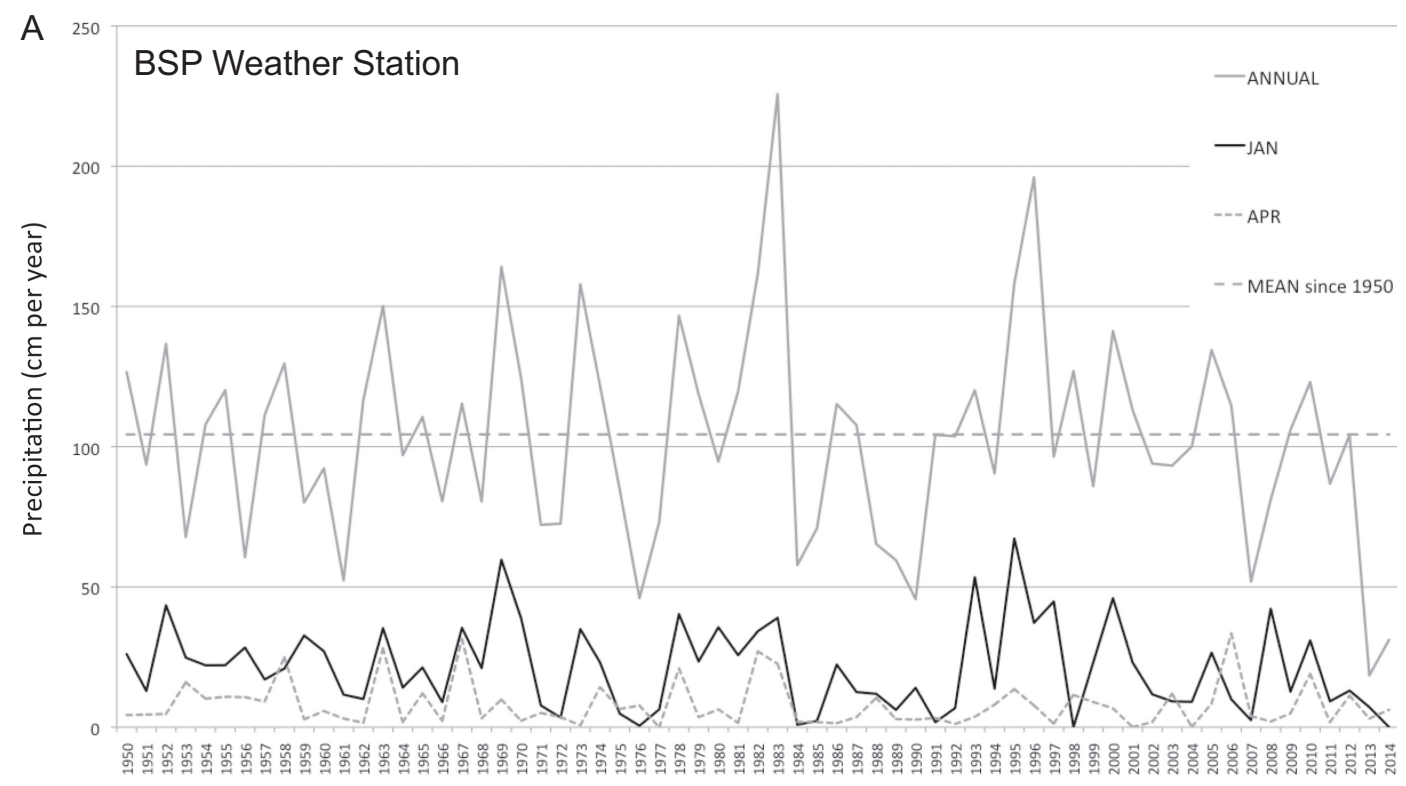

Year

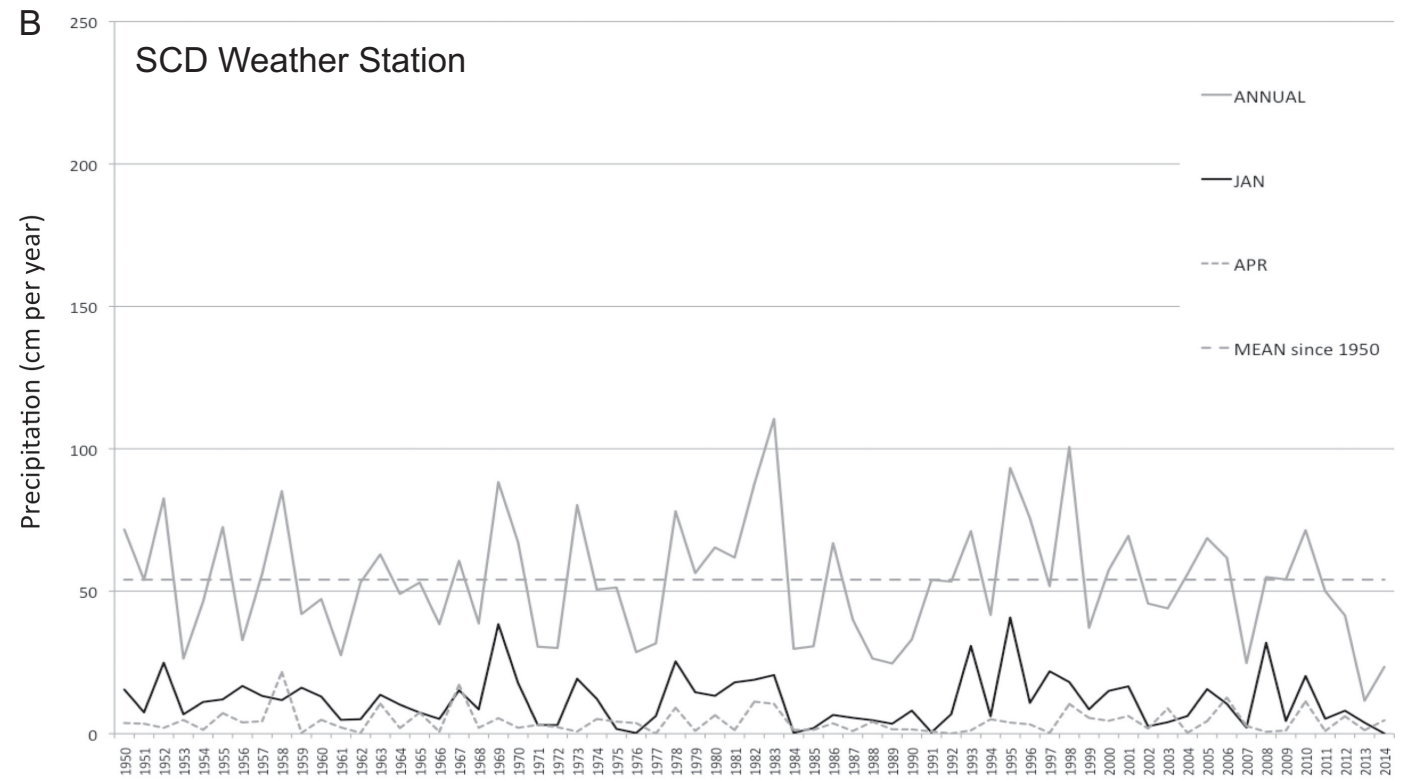

Year

Fig. 4. Annual (and Jan-Apr monthly) precipitation from 1950 to 2014: A, Big Sur State Park (BSP) weather station; B, San Clemente Dam (SCD) weather station.

about $17 \%$ of the long-term mean annual total of $104 \mathrm{~cm}$ recorded at the station from 1950 to 2014 (Fig. 4A). Total precipitation during the first half (Jan-Jun) of 2014 was just $31.2 \mathrm{~cm}$ at the BSP station, which was $47 \%$ of long-term mean precipitation for the first half of the years from 1950 to 2014. Similarly, for 2013 at the SCD weather station, precipitation totaled 

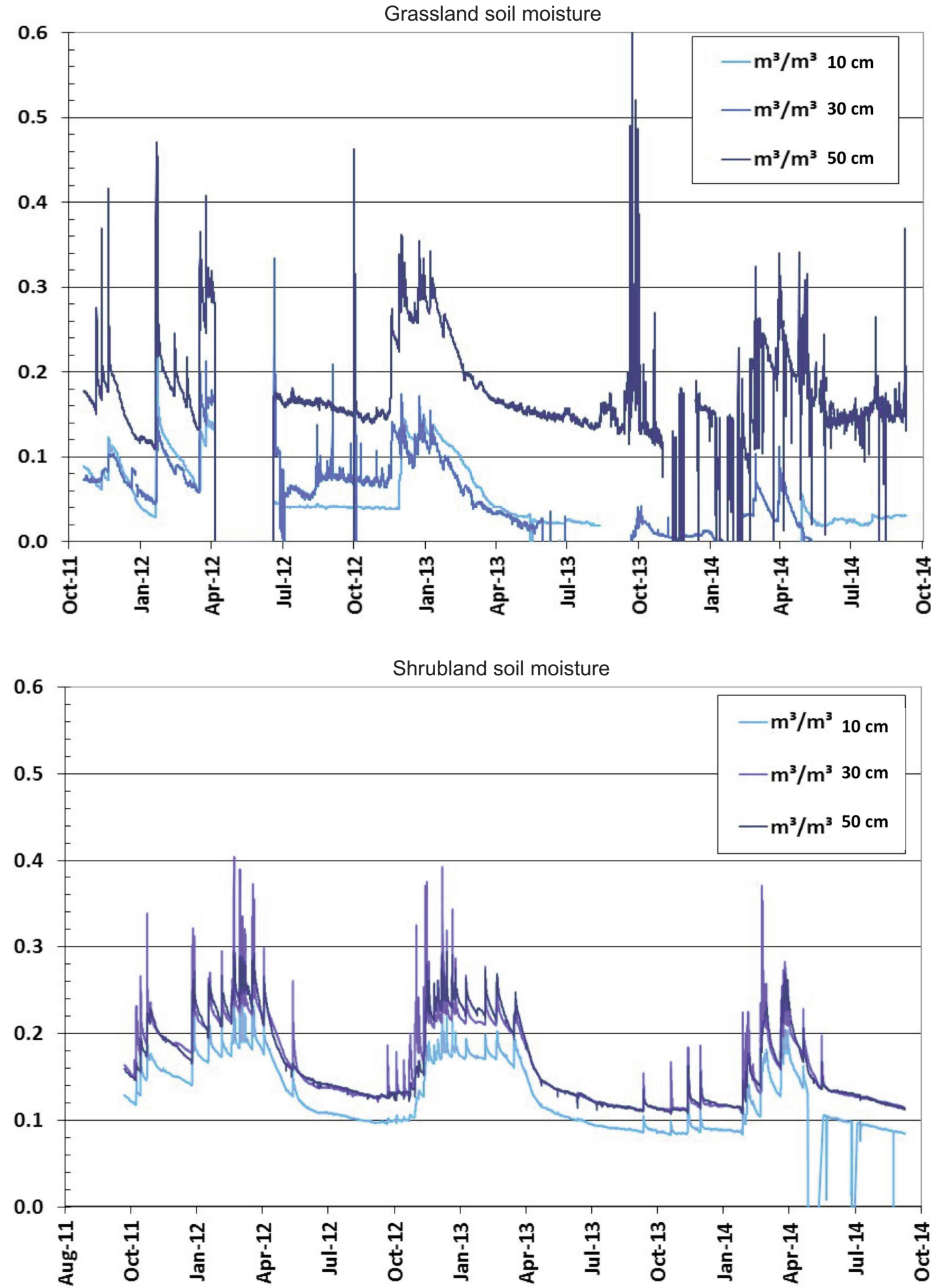

Fig. 5. Caption on facing page. 


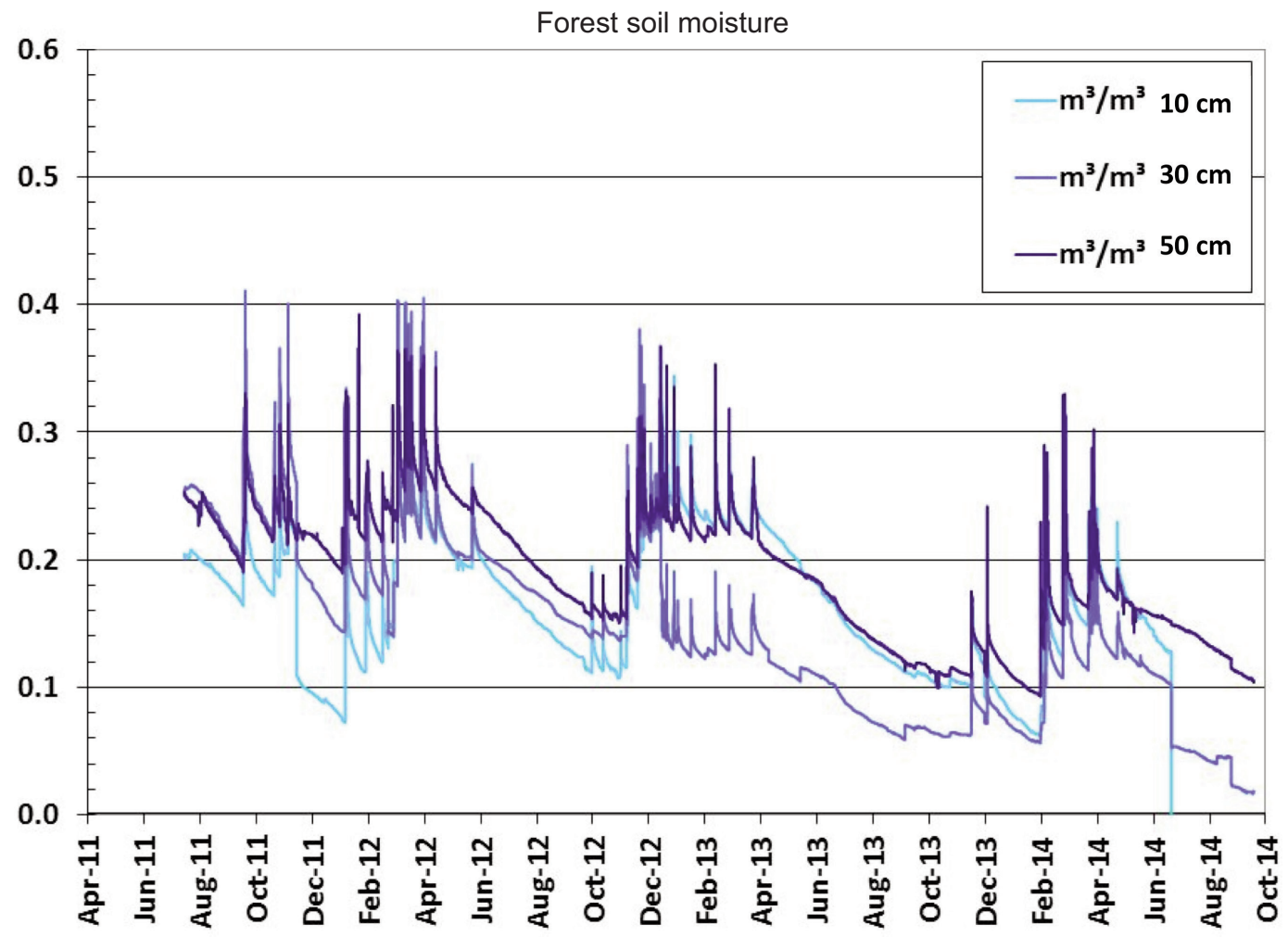

Fig. 5. Plots of hourly soil moisture from 2011 to 2014 at Brazil Ranch measurement stations: grassland, shrubland, and forest.

to $11.6 \mathrm{~cm}$, which was only about $21 \%$ of the long-term mean annual total of $54 \mathrm{~cm}$ recorded at the station (Fig. 4B). Total precipitation during the first half (Jan-Jun) of 2014 was just $23.4 \mathrm{~cm}$ at the SCD station, which was $65 \%$ of long-term mean precipitation for the first half of the years from 1950 to 2014 . For historical context, 2007, 1990, and 1976 were calendar years when $<50 \%$ of the long-term average annual precipitation was recorded at both the BSP and SCD weather stations. Calendar year 2010 was the last previous year with annual precipitation above the long-term average.

Reports of river flow rates and reservoir storage confirmed the exceptional drought status of the study region in 2014. As of midAugust 2014, the Monterey Peninsula Water Management District reported that the Carmel River was no longer flowing out of the Ventana Wilderness Area and into the Los Padres Dam reservoir. As of mid-September 2014, the 2 large dammed reservoirs in the southern section of the study region, San Antonio and
Nacimiento lakes, were reported at $4 \%$ and $17 \%$ of storage capacity, respectively. These storage levels in 2014 were only about $8 \%$ and $47 \%$, respectively, of the storage levels at the same time period in 2012 (California Department of Water Resources 2014).

\section{Soil Moisture Changes}

The record of hourly soil moisture for sites at the Brazil Ranch from 2011 to late 2014 (Fig. 5) showed that the months of May to September 2013 had the lowest consistent VWC at all 3 soil depths during the 3-year time series for these different vegetation cover types. The grassland site at Brazil Ranch was recorded every day of the month from May to September 2013 and 2014 with hourly VWC levels continuously below $20 \%$ at a soil depth of $50 \mathrm{~cm}$. The grassland soil VWC measured at a 10-cm depth was more variable, with rainfall inputs from October to April of these years, but never exceeded 5\% VWC from 1 March to 22 September 2013. In contrast, the shrubland 


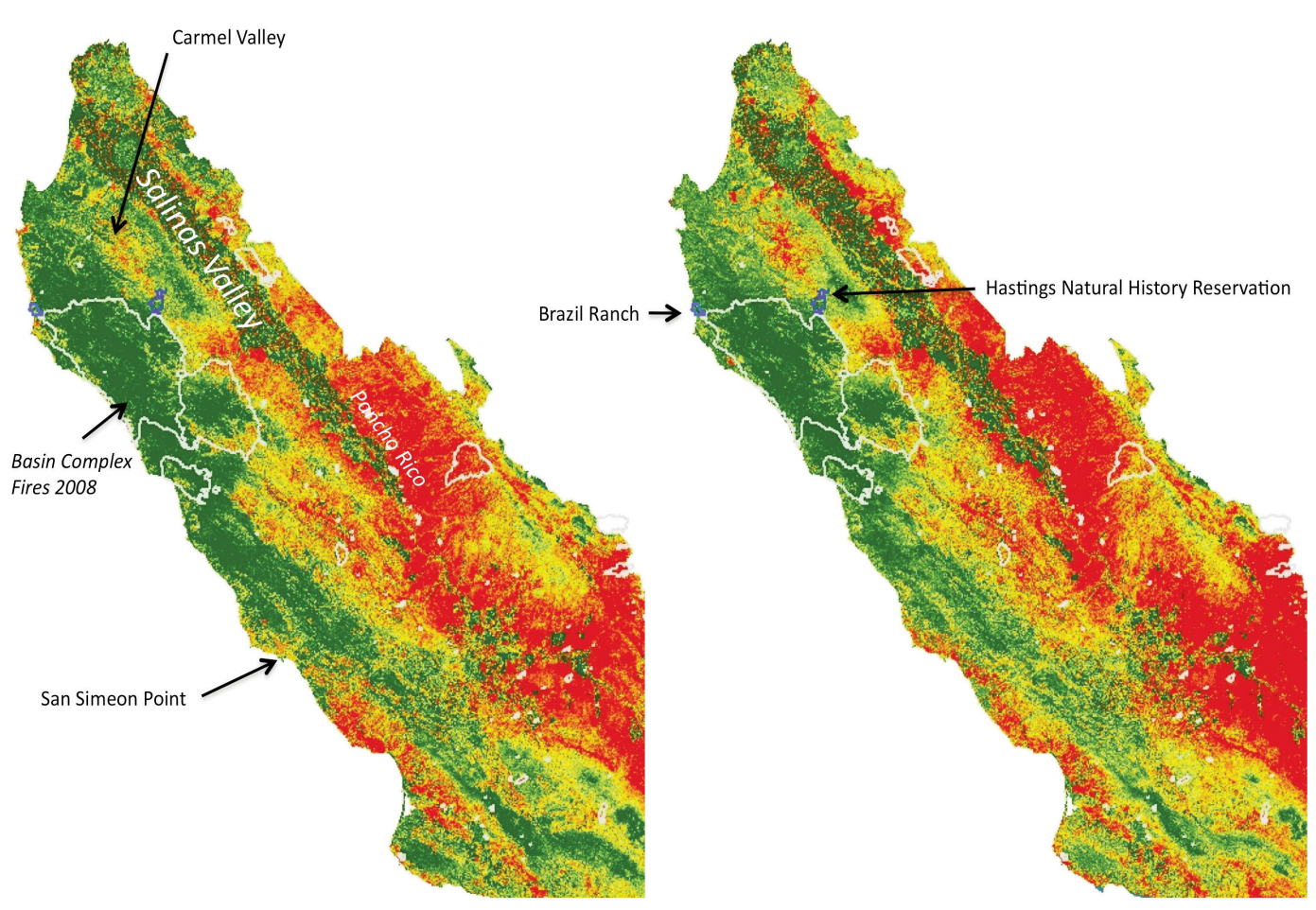

Fig. 6. Landsat 30-m normalized difference water index change maps for May 2013 and May 2014, differenced from May 2010 (predrought) for the study region. Wildfire perimeter boundaries from 2005 to 2012 are shown in gray outlines. Boundaries of the Brazil Ranch and Hastings Natural History Reservation (Carmel Valley) are shown for geographic reference locations in blue outlines.

TABLE 2. Landsat drought stress category values between May of 2010 and 2013/2014 for sites at the Brazil Ranch.

\begin{tabular}{llrrrr}
\hline & & \multicolumn{2}{c}{ RdNDWI } & \multicolumn{2}{c}{ dNDVI } \\
\cline { 3 - 6 } Site number & Vegetation cover & 2013 & 2014 & 2013 & 2014 \\
\hline 1 & Grassland & 246 & -24 & -100 & 78 \\
2 & Shrubland & 22 & 70 & 44 & 66 \\
3 & Forest & -36 & 4 & 40 & 46 \\
\hline
\end{tabular}

and the forest sites were recorded with hourly soil VWC levels at or above $9 \%$ from May to September in both 2013 and 2014 at a $50-\mathrm{cm}$ depth, and at higher than 5\% hourly VWC at a $10-\mathrm{cm}$ depth during these drought periods until June 2014. After June 2014, hourly soil VWC levels at all 3 sites were at (or below) detection levels for the $10-\mathrm{cm}$ and $30-\mathrm{cm}$ depth sensors.

\section{Landsat Drought Assessment}

Change levels in Landsat NDWI and NDVI between May 2010 and May 2013 at the Brazil
Ranch sites (Table 2) corresponded to the differences in VWC measured among the sites during the period from July to September 2013. Specifically, the grassland site was detected with a RdNDWI value in May 2013 of $>200$, whereas the shrubland and forest sites were detected with RdNDWI values $<25$ in May 2013. The low soil moisture grassland response in 2013 implied that RdNDWI values > 200 (and differenced NDVI [dNDVI] values lower than -100) were indicative of high-severity drought impacts on ecosystems of the Central Coast region. 


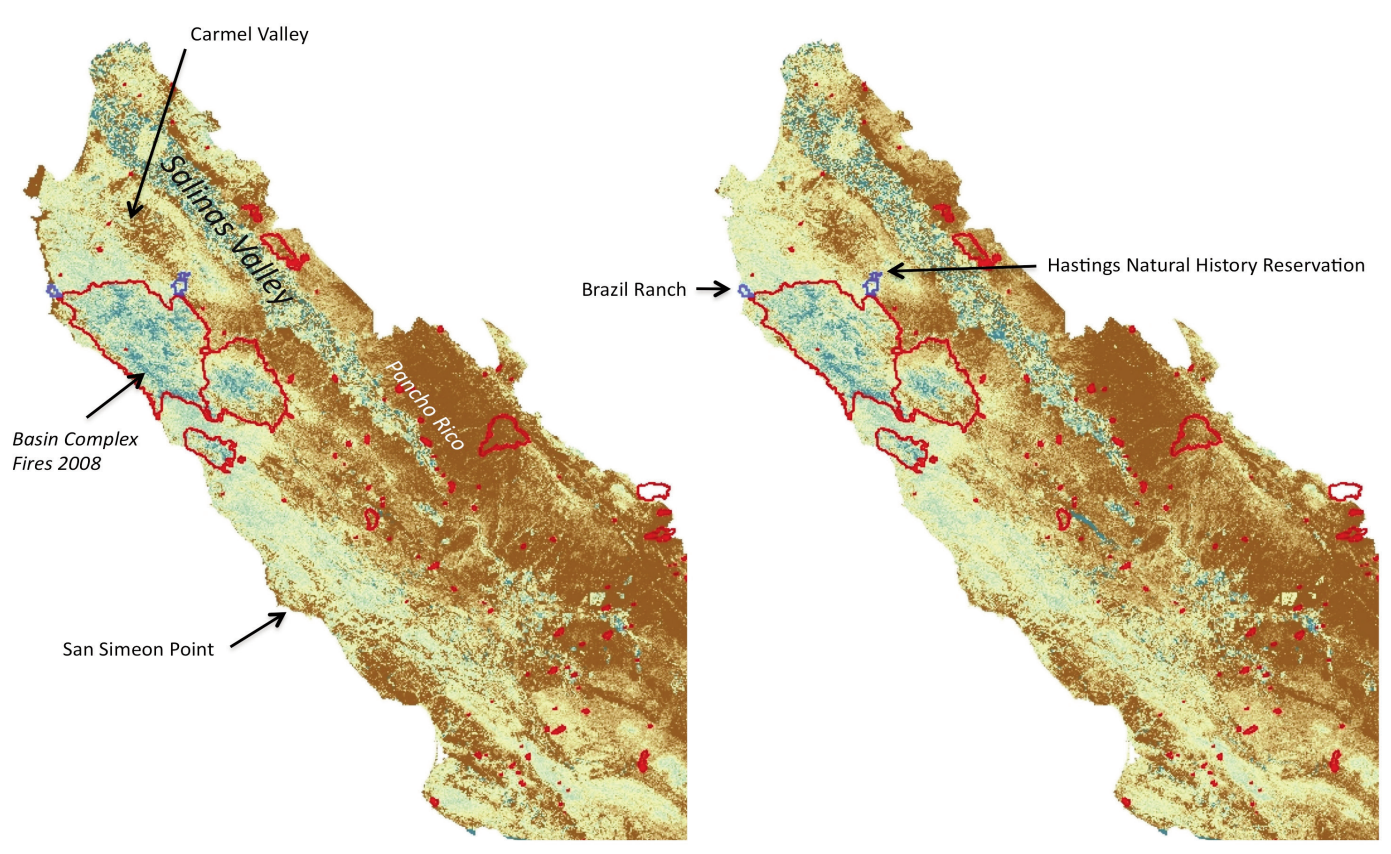

Fig. 7. Landsat 30-m normalized difference vegetation index change maps for May 2013 and May 2014, differenced from May 2010 (predrought) for the study region. Fire perimeter boundaries from 2005 to 2012 are shown in red outlines. Boundaries of the Brazil Ranch and Hastings Natural History Reservation (Carmel Valley) are shown for geographic reference locations in blue outlines.

It should be noted that the changes in Landsat NDWI and NDVI between May 2010 and May 2014 at the Brazil Ranch sites were all well below these high-severity drought thresholds detected in May 2013 (Table 2). The lowered drought stress conditions at Brazil Ranch sites likely resulted from lateseason precipitation events near Big Sur in April 2014, which totaled to about $6 \mathrm{~cm}$ of rainfall at the BSP weather station.

According to differences in Landsat NDWI and NDVI at the regional level between May 2010 and May 2013 (Figs. 6, 7), geographic areas within the larger study region that were most severely impacted by the 2013 drought were the inland Carmel Valley in northern Monterey County, and the coast zones around San Simeon Point and Cambria in northern San Luis Obispo County. An expanded area of severe vegetation moisture stress, indicated by RdNDWI values $>400$, was detected by May 2014 in both of these same geographic areas.

For more detailed examination of drought impacts, the entire study region was separated into 3 predominant vegetation types (grasslands, shrublands, and forests) to examine changes in Landsat NDWI and NDVI in the context of differing plant community responses to extreme drought. Results indicated that, by May 2013, 89\% of all grasslands and $51 \%$ of all shrublands in the study region showed relatively high drought stress, with Landsat RdNDWI values $>200$. In contrast, only $4.7 \%$ of all forest cover in the study region showed this level of relatively high drought stress.

Within each vegetation cover type, 1000 points were randomly selected for statistical comparisons and were further characterized according to elevation, slope, aspect, and recent wildfire history. Results showed that a significant difference $(\mathrm{K}-\mathrm{S}$ test: $P<0.01)$ was detected between the frequency distribution of grassland RdNDWI (mean RdNDWI > 440) and dNDVI (mean dNDVI < - 170) for both 2013 and 2104, compared to the frequency distribution of RdNDWI and dNDVI of both shrublands and forests in the corresponding years, with grasslands showing more 
TABLE 3. Comparison of Landsat drought stress category values between May of 2010 and 2013/2014 among the 3 predominant vegetation cover types in the Central Coast study region. Mean (SE) category values (for $N=1000$ randomly selected locations) showed significant differences at $P<0.01$ (Kolmogorov-Smirnov nonparametric test) among all 3 vegetation cover types in both drought stress categories.

\begin{tabular}{lcccc}
\hline & \multicolumn{2}{c}{ RdNDWI } & \multicolumn{2}{c}{ dNDVI } \\
\cline { 2 - 3 } \cline { 5 - 5 } Vegetation type & 2013 & 2014 & 2013 & 2014 \\
\hline Grasslands & $448(5)$ & $501(4)$ & $-182(1)$ & $-177(1)$ \\
Shrublands & $200(4)$ & $236(4)$ & $-76(1)$ & $-80(1)$ \\
Forests & $-26(2)$ & $29(2)$ & $29(1)$ & $3(1)$ \\
\hline
\end{tabular}

severe drought stress overall (Table 3). Shrublands were also detected with more significant drought stress (mean RdNDWI $>200$ and dNDVI $<-70$ ) overall than forest locations. Although no significant differences (at $P<$ 0.05 ) could be detected in any of the 3 vegetation types between 2013 and 2014 frequency distributions of RdNDWI or dNDVI, mean values of RdNDWI for 2014 were slightly more extreme than for 2013 for all 3 vegetation types.

Plots of sampled RdNDWI and dNDVI values by elevation and slope for each of the 3 predominant vegetation types (Figs. 8, 9, 10) confirmed higher overall drought stress detected in grasslands compared to shrublands and forests in both years at all elevations and slopes $>200 \mathrm{~m}$ and $>5 \%$, respectively. Drought stress in shrublands tended to peak at between $400 \mathrm{~m}$ and $500 \mathrm{~m}$ elevation in both years. Drought stress in forests tended to be slightly higher overall at all elevations below $1000 \mathrm{~m}$ and on slopes of $<10 \%$. There was no significant variation by aspect in the Landsat drought stress categories in either year for any of the 3 vegetation types.

It was evident from a regional viewpoint that changes in Landsat NDVI between May of 2010 and 2013/2014 were elevated in the high-burn-severity areas of the 2008 Basin Complex fire (labeled in Fig. 7) compared to surrounding unburned areas. This relationship of vegetation regrowth patterns in recent wildfire areas (2005-2012) to lowered vegetation drought stress was further confirmed for the sampled frequency distribution of shrubland locations, with unburned locations showing mean RdNDWI > $260(N=782)$ in both 2013 and 2014, whereas recently burned shrubland locations showed much lower drought stress, with mean RdNDWI $<-15(N=218)$ in both 2013 and 2014. Similarly, unburned forest locations showed mean RdNDWI $=170$
$(N=697)$ in 2014 , whereas recently burned forest locations showed lowered drought stress, with mean RdNDWI $=-152(N=303)$ in 2014. Less than $2 \%$ of all grassland areas sampled were categorized as recently burned, which indicated that wildfire was a not a major factor influencing the drought response of these herbaceous vegetation communities across the study region.

\section{Discussion}

Rainfall records from weather stations in the study region revealed that exceptional drought conditions were experienced in 2013 across the Central Coast area of California at $17 \%-21 \%$ of long-term average annual rainfall totals compared to a statewide $30 \%$ of average in 2013, compared to long-term rainfall totals (Hanak et al. 2014). In contrast to grasslands and pasture lands on the Central Coast, by May 2013 (prior to the Pfeiffer Ridge fire), $<5 \%$ of all forest cover area in the study region showed relatively high drought stress (Landsat RdNDWI > 200). Within areas burned by wildfire since 2005 across the study region (made up of $90 \%$ forest and shrubland cover), $<2 \%$ of all forest cover burned showed relatively high drought stress. This was compared to $31 \%$ of all shrubland cover that showed relatively high drought stress (RdNDWI > 200) within burned areas. The overall conclusion from these results was that forested areas in the study region were much less affected by moisture deficits in 2013 compared to shrublands, particularly within recently burned areas where young trees recovering from wildfire continued to show increases in green leaf cover and near-normal canopy moisture levels.

The results from this Landsat image analysis showed that grasslands on the Central Coast were the ecosystems under the highest drought stress in 2013 and 2014. Statewide 

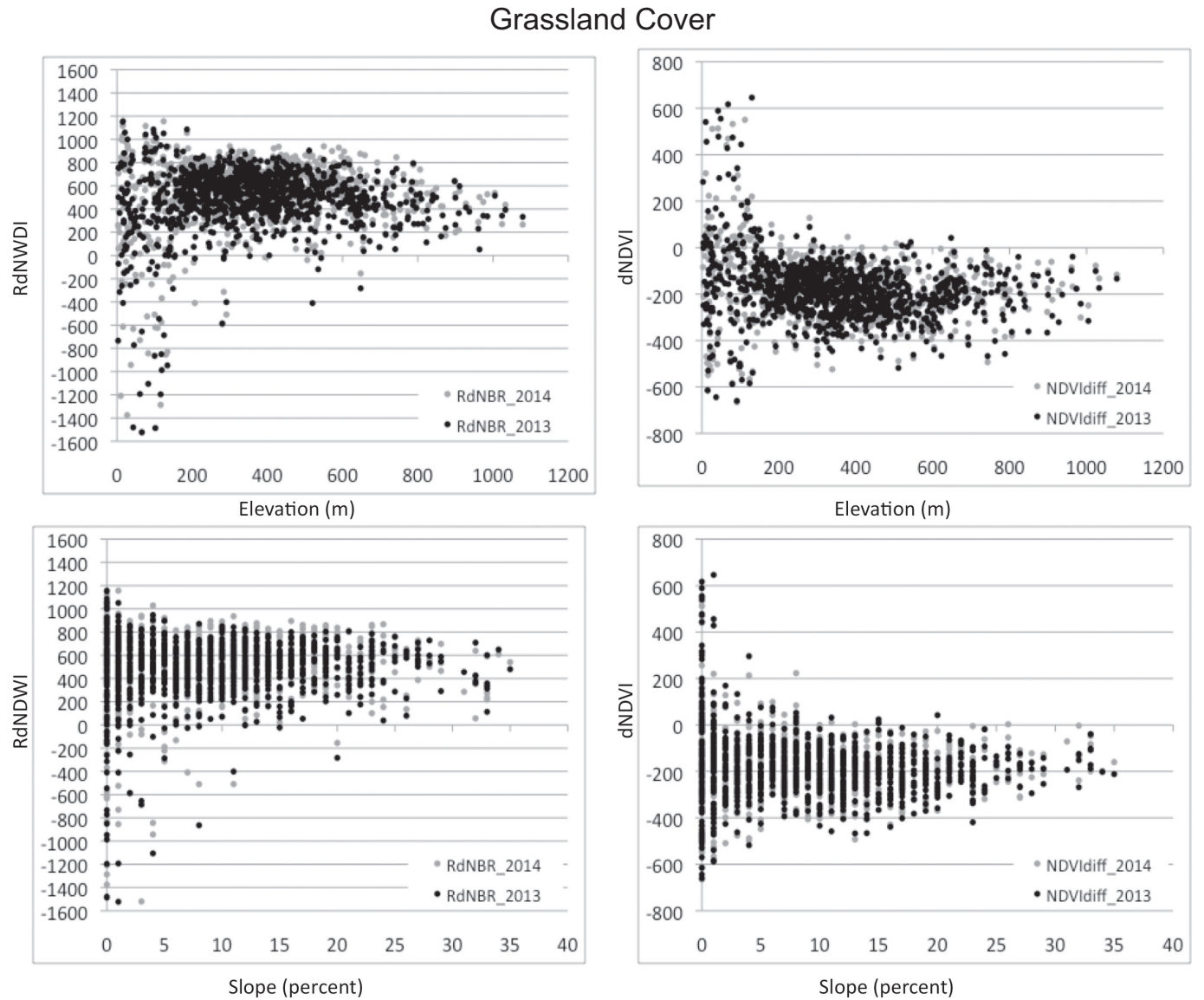

Fig. 8. Plots of Landsat relative-differenced normalized difference water index and differenced normalized difference vegetation index by elevation and slope, sampled at 1000 randomly selected locations within grassland cover across the study region.

drought assessments have likewise reported that dairy and cattle ranchers have been among the first landowners to be impacted by California water shortages, because livestock require forage year-round (Howitt et al. 2014). In contrast, valley crop growers typically have until mid-March to make planting decisions.

Statewide assessments have reported that the lack of rainfall in the winter of 2013/14 substantially reduced the quality of nonirrigated pasture and the number of cattle per acre during the crucial periods of calving and raising of feeder cattle on pasture. This lack of pasture feed caused ranchers to sell many cattle out of the state, often to save irrigation water for higher-value nonforage crops. The drought increased 2014 alfalfa hay prices in the state by nearly $20 \%$ compared to 2013 , making feedlot operations more expensive.
Howitt et al. (2014) projected a 3\% loss of revenue for the California livestock sector in 2014 due to lack of pasture and forage, and a $\$ 100$ million reduction in statewide gross revenues.

The native perennial grasses of the Central Coast region can survive droughts and then regenerate during subsequent rainfall periods (Hamilton et al. 2002). Small patches of perennial grasses, often found at the periphery of open herbaceous cover areas (Stromberg and Griffin 1996), will persist in a nongreen state during prolonged droughts. Landsat images in areas of high native grass and forb cover would thereby observe a high fraction of what appears to be barren soil in what are classified as grasslands from satellite mapping data.

Satellite image analysis provides a high level of spatial detail in the assessment of drought impacts that no other regional monitoring 

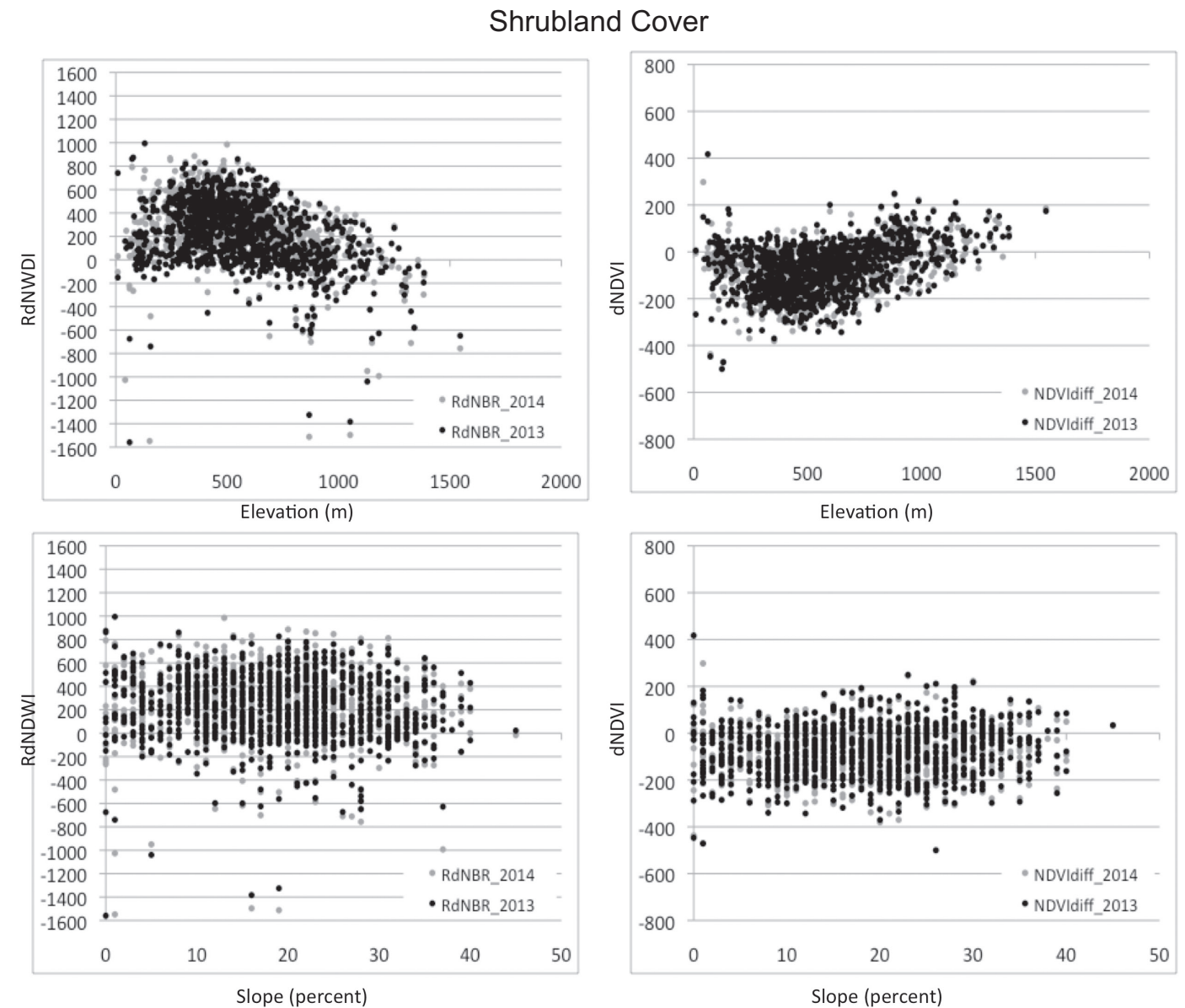

Fig. 9. Plots of Landsat relative-differenced normalized difference water index and differenced normalized difference vegetation index by elevation and slope, sampled at 1000 randomly selected locations within shrubland cover across the study region.

methodology can match. An important management use of the Landsat products generated in this study will be to estimate the potential fire fuel loads of dry woodland and shrubland vegetation biomass that will be susceptible to burning, which could severely damage nearby residential and commercial buildings in the years to come. The effectiveness of wildfire fuel management treatments at many locations on the Big Sur coast can be readily assessed and compared during the next few dry seasons by public land managers and private property owners.

The results from this study will set the stage for at least 2 lines of ecological research on the California Central Coast region in the (postdrought) years that will follow. The first research effort will be to investigate the role of summer fog deposition in mitigating the lack of winter rainfall in California coastal ecosystems. Hiatt et al. (2012) presented preliminary data to support the hypothesis that shrub cover on the California coast intercepts moisture from fog deposition that may help sustain the productivity of this vegetation community through periods of low precipitation. Experiments can be designed to determine the wind and humidity conditions under which coastal shrub foliage may trap advected fog water and drip moisture into the surrounding soil below to mediate losses due to evapotranspiration.

The second research effort will be to develop effective methods to monitor changes in vegetation habitats for rare and endangered species on the Big Sur coast. This type of postdrought plant species monitoring dates back 
Forest Cover
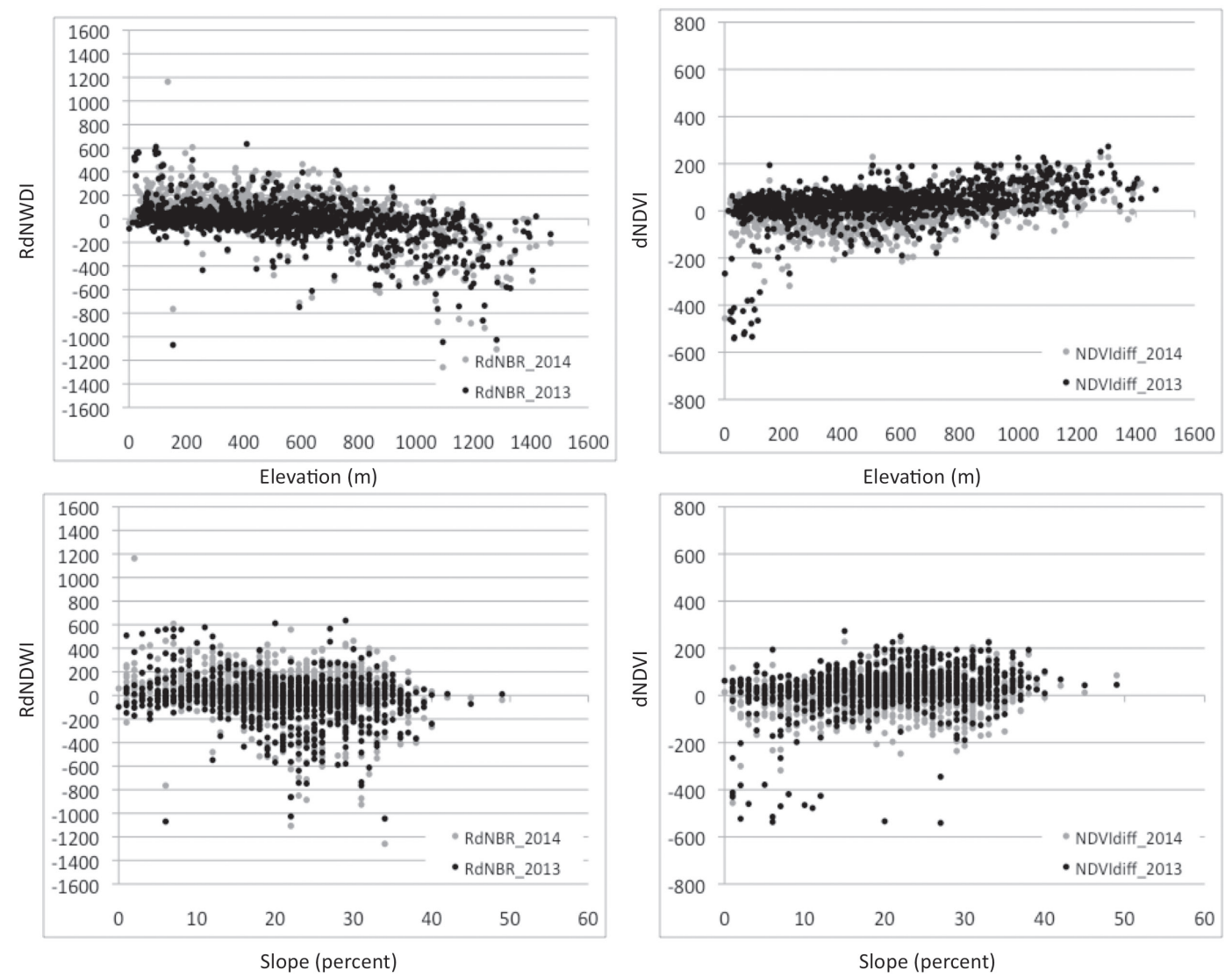

Fig. 10. Plots of Landsat relative-differenced normalized difference water index and differenced normalized difference vegetation index by elevation and slope, sampled at 1000 randomly selected locations within forest cover across the study region.

to the mid-20th century (Weaver and Albertson 1943). Today, the Central Coast serves as a refuge for biological species with a low tolerance for climate warming trends (Henson and Usner 1996). If extreme summer temperatures observed in the coastal weather station records since the mid-1990s (Potter 2014a) continue as long-term climate change occurs farther along the California coastal region, the productivity and health of coastal rangelands and surrounding vegetation habitats may be altered in unanticipated ways. Changes in growing season initiation date and duration for native plant species may result from climate warming. Future droughts may have large impacts on river and steam flows on the Pacific coast. Under current regulations, the harvest of hatchery trout and steelhead is allowed on the Big Sur River and tributaries above the upstream end of the gorge pool at the boundary of Pfeiffer Big Sur State Park with the Ventana Wilderness Area. However, this section of the Big Sur River is above a fish barrier and is not reachable by anadromous salmonids. Therefore, in large part due to low stream flows during the 2013/14 drought, the California Fish and Game Commission has proposed to remove the current regulatory language authorizing the harvest of hatchery trout and steelhead and return this section of the Big Sur River to catch-and-release angling.

Growth of invasive plant species and pathogens can be altered during drought periods as well. A prime example is sudden oak death (SOD), an exotic disease caused by the microscopic pathogen Phytophthora ramorum, introduced to California 20-25 years ago. Managing the presence of California bay laurel 
(Umbellularia californica), the primary carrier of $P$. ramorum in California, around high-value native oak stands in the Big Sur region may reduce the number of infectious SOD spores. In 2014, only 8 of 170 bay laurel trees surveyed near the Post Ranch in Big Sur tested positive for SOD disease; only 1 tree out of 104 tested at Pfeiffer Big Sur State Park tested positive for SOD (Garbelotto 2014). During the recent period of relatively low SOD spread, selective removal and pruning of droughtstressed bay laurel trees may be an effective strategy to protect native oaks from further SOD infection.

In summary, sudden shifts in climate and the frequency of extreme weather events, such as the 2013/14 drought, have the potential to tip the balance in favor of or against vulnerable biological resources and the human activities that sometimes require a struggle to prosper in a remote and rugged coastal environment such as the California Central Coast. Reliable, low-cost monitoring methods of the regional land cover are an essential part of the ongoing effort to prepare for future droughts.

\section{ACKNOWLEDGMENTS}

The author acknowledges the cooperation of the U.S. Forest Service for access to the Brazil Ranch property and for collaboration on climate-ecosystem science investigations in Big Sur. Thanks also to Chris Hauser and Leslie Dorrance of the Santa Lucia Conservancy and Sarah Hardgrave of the Big Sur Land Trust for feedback on the potential support for land management decisions from satellite image analysis.

\section{Literature Cited}

Abatzoglou, J.T., K.T. Redmond, and L.M. Edwards. 2009. Classification of regional climate variability in the state of California. Journal of Applied Meteorology and Climatology 48:1527-1541.

Avery, T.E., and G.L. Berlin. 1992. Fundamentals of remote sensing and airphoto interpretation. Prentice Hall, Upper Saddle River, NJ. 472 pp.

Burrough, P.A., And R.A. McDonell. 1998. Principles of geographical information systems. Oxford University Press, New York, NY. 190 pp.

California Department of Forestry, Fire and Resource Assessment Program. 2014. Fire and Resource Assessment Program [web application]. http://frap.cdf.ca.gov/

California Department of Water Resources. 2014. California Data Exchange Center-Reservoirs. http://cdec.water.ca.gov/reservoir.html
Chander, G., B. Markham, and D. Helder. 2009. Summary of current radiometric calibration coefficients for Landsat MSS, TM, ETM+, and EO-1 ALI sensors. Remote Sensing of the Environment 113: 893-903.

Chuvieco, E., D. Riano, I. Aguado, and D. Cocero. 2002. Estimation of fuel moisture content from multitemporal analysis of Landsat Thematic Mapper reflectance data: application in fire danger assessment. International Journal of Remote Sensing 23: 2145-2162.

Corbin, J.D., M.A. Thomsen, T.E. Dawson, and C.M. D'AnTonio. 2005. Summer water use by California coastal prairie grasses: fog, drought, and community composition. Oecologia 145:511-521.

Daly, C., M. Halbleib, J.I. Smith, W.P. Gibson, M.K. Doggett, G.H. Taylor, J. Curtis, and P.A. PasTERIS. 2008. Physiographically sensitive mapping of temperature and precipitation across the conterminous United States. International Journal of Climatology 28:2031-2064.

Dennison, P.E., D.A. Roberts, S.H. Peterson, and J. RECHEL. 2005. Use of normalized difference water index for monitoring live fuel moisture. International Journal of Remote Sensing 26:1035-1042.

De Santis, A., G.P. Asner, P.J. Vaughan, and D.E. KnapP. 2010. Mapping burn severity and burning efficiency in California using simulation models and Landsat imagery. Remote Sensing of Environment 114: $1535-1545$.

Eidenshink J., B. Schwind, K. Brewer, Z. Zhu, B. QuaYle, AND S. Howard. 2007. A project for monitoring trends in burn severity. Fire Ecology Special Issue 3:3-21.

GAO, B.C. 1996. NDWI-a normalized difference water index for remote sensing of vegetation liquid water from space. Remote Sensing of Environment 58: $257-266$.

Garbelotto, M. 2014. UC Berkeley Forest Pathology and Mycology Lab. http://nature.berkeley.edu/garbelot towp/

Hamilton, J.G., J.R. Griffin, and M.R. Stromberg. 2002. Long-term population dynamics of native Nassella bunchgrasses in unmanaged stands in central California. Madroño 49:274-284.

Hanak, E., J. Mount, and C. Chappelle. 2014. California's latest drought. Public Policy Institute of California February 2014. http://www.ppic.org/main/ publication_show.asp?i $=1087$

Henson, P., AND D.J. UsNer. 1996. The natural history of Big Sur. University of California Press, Berkeley, CA. 416 pp.

Hiatt, C., D. Fernandez, and C. Potter. 2012, Measurements of fog water deposition on the California Central Coast. Atmospheric and Climate Sciences 2:525-531.

Howitt, R.E., J. Medellin-Azuara, D. MacEwan, J.R. Lund, AND D.A. Sumner. 2014. Economic analysis of the 2014 drought for California agriculture. Center for Watershed Sciences, University of California, Davis, CA.

Hunt, E.R, AND B.N. Rock. 1989. Detection of changes in leaf water content using near and middle-infrared reflectances. Remote Sensing of Environment 30: 43-54.

Lehmann, E. 2006. Nonparametrics: statistical methods based on ranks. Springer, New York, NY. 464 pp. 
Lentile, L., Z.A. Holden, A. Smith, M. Falkowski, A Hudak, P. Morgan, S. Lewis, P. Gessler, and N. BENSON. 2006. Remote sensing techniques to assess active fire characteristics and post-fire effects. International Journal of Wildland Fire 15:319-345.

LI, S., AND C.S. PotTER. 2012. Patterns of aboveground biomass regeneration in post-fire coastal scrub communities. GIScience and Remote Sensing 49:182-201.

Miller, J.D., AND S.R. YoOL. 2002. Mapping forest postfire canopy consumption in several overstory types using multi-temporal Landsat TM and ETM data Remote Sensing of Environment 82:481-496.

[NASA] National Aeronautics and Space AdministraTION. 2014. MODIS [web application]. http://modis .gsfc.nasa.gov/

National Agricultural Statistics Service. 2012. CropScape-Cropland Data Layer. http://nassgeodata .gmu.edu/CropScape

PotTer, C. 2014a. Understanding climate change on the California coast: accounting for extreme daily events among long-term trends. Climate 2:18-27.

PotTer, C. 2014b. Microclimate influences on vegetation water availability and net primary production in coastal ecosystems of Central California. Landscape Ecology 29:677-687.

Shreve, F. 1927. The vegetation of a coastal mountain range. Ecology 8:27-44.
StromberG, M.R., And J.R. Griffin. 1996. Long-term patterns in coastal California grasslands in relation to cultivation, gophers and grazing. Ecological Applications 6:1189-1211.

[USGS] U.S. Geological Survey. 2001. National Land Cover Database 2001 [web application]. http://www .mrlc.gov/nlcd2001.php

[USGS] U.S. Geological Survey. 2014a. Earth Explorer [web application]. http://earthexplorer.usgs.gov/

[USGS] U.S. Geological Survey. 2014b. National Elevation Dataset [web application]. http://ned.usgs.gov/

Van Wagtendonk, J.W., and R.R. Root. 2003. The use of multi-temporal Landsat Normalized Difference Vegetation Index (NDVI) data for mapping fuel models in Yosemite National Park, USA. International Journal of Remote Sensing 24(8):1639-1651.

Weaver, J.E., and F.W. Albertson. 1943. Resurvey of grasses, forbs and underground plant parts at the end of the great drought. Ecological Monographs 13:64-117.

[WRCC] Western Regional Climate Center. 2014. Cooperative Climatological Data Summaries. http:// www.wrcc.dri.edu/climatedata/climsum

Received 1 December 2014 Accepted 20 March 2015 